Canterbury Earthquake Recovery Public Forum, Oxford Terrace Baptist Church, Christchurch

Sat $6^{\text {th }}$ November 2010

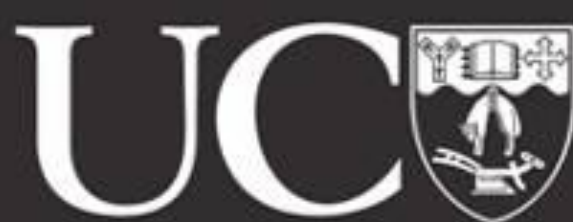

UNIVERSITY OF CANTERBURY

Te Whare Wananga o Waitaha CHRISTCHURCH NEW ZEALAND

\title{
Sustainability and Resilience
}

Assoc. Prof. Simon Kingham

Dept of Geography and GeoHealth Laboratory University of Canterbury 


\section{Changing society}

We live in a world of change and disruption - now and future

- Peak oil

- Climate change

- Earthquakes

Resilient and sustainable communities essential Increasing reliance on local not global community

"Our lives will become profoundly and intensely local" - Kames Kunstler, Local Emergency, 2006. 


\section{Wide acceptance}

"In the first 24-48 hours of a disaster, the community bears the burden of response. It is a fallacy to rely on external help"

- Roderico Ofrinm, WHO SE Asia adviser for emergency and humanitarian action

"The challenge for urban planners will be ... to generate a sense of hope through a combination of new technology, city design and communitybased innovation, which together will create the Resilient City."

- Prof Peter Newman, academic \& member of Infrastructure Australia 


\section{... even in the US}

"I encourage all Americans to recognize the importance of preparedness and observe this month by working together to enhance our national security, resilience, and readiness."

- President Barack Obama, Presidential Proclamation, National Preparedness Month, August 27, 2010

"We gotta get off oil, America has got to change its habits,"

- George W. Bush, March 5th 2008 


\section{Sustainable resilient communities}

\section{What are sustainable resilient communities?}

Communities that:

- Are less reliant on fossil fuels

- Produce less harmful outputs (e.g. pollution, carbon)

- Use less finite inputs (e.g. water, energy)

- Reliant on local rather than global goods \& services

- Are better able to adapt to change

- Quicker to recover when disrupted 


\section{Evidence for existence}

Communities can be resilient

- Nov 07-April 08 - Americans drove 30 billion fewer $\mathrm{kms}$ that 06-07 (June 08 was peak oil price of $\$ 140$ per barrel)

- Sept $4^{\text {th }}$ when EQ hit Christchurch, local communities stepped up

- Growth in Transition Initiative communities 


\section{Initiatives}

\section{Transition Initiatives}

- Aim is to equip communities (regions, cities, suburbs) for the dual challenges of climate change and peak oil

Can also apply to other challenges e.g. earthquake response and recovery

- Behaviour change is essential

Key is to raise awareness of sustainable living

Role of government is to facilitate this change among individuals and communities 


\section{Co-benefits}

\section{People who live in local resilient communities:}

- Walk and cycle more

$\checkmark$ Improved health

$\checkmark$ Better social capital

$\checkmark$ Other benefits 


\section{More co-benefits}

Communities that promote active and sustainable transportation can:

- Reduce disparities between the rich and poor

- Promote good neighbourhood

- Enable poor to gain better access to healthy food

- Lead to decreased crime

- OECD Project on Environmentally Sustainable Transport 


\section{Concluding comments}

- Resilience $\neq$ sustainable

- Resilience can = sustainable

- Opportunity to rebuild resilient AND sustainable communities

- Concern about 'special powers'

- Use them

- Outside-the-square thinking needed 